\title{
Synthesis and characterization of aluminum-based adsorbent and application in fluoride removal from aqueous solution
}

\author{
Jihane Assaoui *, Zineb Hatim and Abdelmoula Kheribech \\ Chouaïb Doukkali University, Faculty of Science, Water and Environment Team, \\ Laboratory "Biomaterials and Electrochemistry", El Jadida, Morocco
}

\begin{abstract}
A novel adsorbent was obtained by a facile precipitation method and was used for fluoride removal from aqueous solution. Mineralogical and physicochemical characterization of the adsorbent was carried out by X-Ray Diffraction (XRD), X-Ray Fluorescence (XRF), Energy Dispersive X-Ray attached to Scanning Electron Microscopy (SEM-EDX), BET Specific Surface Area(SSA N2BET $_{\text {) }}$ analysis and Fourier-Transform Infrared Spectrometry (FTIR). The effect of various operational parameters such as contact time, initial fluoride concentration, (20-160 mg L-1) adsorbent dose (1-6 $\left.\mathrm{g} \mathrm{L}^{-1}\right)$ and initial $\mathrm{pH}$ solution (3-11) was evaluated in batch procedures at room temperature $\left(25 \pm 2^{\circ} \mathrm{C}\right)$. The results of the batch adsorption experiments proved that $24 \mathrm{~h}$ of contact time was sufficient for attaining equilibrium. The maximum wastewater defluoridation $(84.91 \%)$ was obtained for $40 \mathrm{mg} \mathrm{L}^{-1}$ and $3 \mathrm{~g} \mathrm{~L}^{-1}$ of initial fluoride concentration and adsorbent dose, respectively. It appears that there was no significant effect on the $\mathrm{F}^{-}$removal over a wide range of $\mathrm{pH} 3-11$. Kinetic studies revealed that fluoride adsorption fitted well to pseudo-second-order. The adsorption isotherm of fluoride sorption indicated that the maximum adsorption capacity was noted to be $43.29 \mathrm{mg} \mathrm{g}^{-1}$. Batch adsorption data was better described by Langmuir isotherm confirming monolayer adsorption with homogenous distribution of active sites and without interaction between adsorbed molecules. The obtained results indicated that the ion exchange is probably the main mechanism involved in the $\mathrm{F}^{-}$adsorption by the aluminium-based adsorbent.
\end{abstract}

Keywords: Fluoride, Aqueous solution, Aluminum-based adsorbent, Kinetic studies, Adsorption isotherms.

\section{Introduction}

Fluoride, a naturally occurring element present in the soil, water, food and several minerals composition ${ }^{1,2}$. It is an essential trace element for the human body for the dental calcification enamel and maintenance of healthy bones. Furthermore, fluoride is widely used in the organic drug industry ${ }^{3,4}$, fluorinated polymers ${ }^{5,6}$, surfactants ${ }^{7,8}$, battery components 9, etc. However, fluoride contamination has been recognized as a serious problem worldwide, an excess of this element can lead to ecological damage ${ }^{10}$. This excess is mainly due to the dissolution of natural minerals like fluorapatite and fluorite in the aquatic environment ${ }^{11}$. Volcanoes can also lead to the release of gases containing hydrogen fluoride into the atmosphere before its transfer to the aquatic ecosystem ${ }^{12,13}$. In addition to natural sources, fluoride may also be found in industrial wastes such as semiconductor industries ${ }^{14-16}$ the metal surface treatment ${ }^{17}$, the fertilizers production ${ }^{18}$, the application of the fertilizers and pesticides in the agriculture, and glass manufacturing ${ }^{19,20}$. The discharge of these industrial effluents can lead to an increase in the fluoride level in the receiving aqueous media (ex: groundwater

*Corresponding author: Jihane Assaoui

Email address: assaoui.j@ucd.ac.ma

DOI: http://dx.doi.org/10.13171/mjc101020291172ja table) where they are transferred by infiltration which can lead to environmental and health impacts ${ }^{21-24}$. In fact, recent literature reports that an excessive fluoride amount can produce toxic effects in animals and plants such a way that the fluoride ions act as enzyme poisons, inhibiting enzymatic activity and interrupting metabolic processes like the glycolysis and plant protein synthesis ${ }^{25}$.

Moreover, the high concentrations of fluoride can inhibit or increase the algae population growth and lead to a decrease in oxygen levels in aquatic systems ${ }^{22}$. Recently many scientific reports seem to suggest that fluoride intake may be associated with a number of human health problems ${ }^{26-28}$, for instance osteoporosis ${ }^{29,30}$, arthritis, bone fragility ${ }^{31}$, brain damage ${ }^{32}$, etc. Due to these impacts on human health and environment, a number of international regulators have issued regulations to control the fluoride levels in water ${ }^{33,34}$. Different processes have been studied to remove excessive fluoride from water namely, biological processes (plants or microorganisms) ${ }^{35,36}$ and physicochemical processes such as fluidized bed precipitation 37 , electrocoagulation-flotation ${ }^{38,39}$, ion-exchange ${ }^{40,41}$, 
electrochemical methods ${ }^{42}$ and membrane processes (reverse osmosis ${ }^{43,44}$,

electrodialysis ${ }^{45,46}$, Donnan dialysis ${ }^{47}$, nanofiltration ${ }^{48}$, etc.). However, each of these methods presents its drawbacks, such as a long disposal time, the use of dangerous and expensive reagents ${ }^{49}$. Among these methods, adsorption is mentioned as the most efficient and widely used fundamental approach in water defluoridation processes ${ }^{50}$. It is characterized by its simplicity and availability of a wide variety of adsorbents. The adsorption capacity and adsorbents affinity are determined by the textural and physical properties as well as their surface chemical nature ${ }^{51}$. A large variety of adsorbents has been reported in literature, such as iron-based materials ${ }^{52}$, kaolinite ${ }^{53}$, bentonite ${ }^{54}$, lignite ${ }^{55}$, calcite ${ }^{56}$, tricalcium phosphate ${ }^{57}$, hydroxyapatite ${ }^{58}$, red mud ${ }^{59}$, montmorillonite ${ }^{60}$, Alumina has been reported in the literature as an active support for water defluoridation due to its sorption properties, ion exchange potential and low cost ${ }^{61,62}$. However, its adsorption capacity is not always satisfactory, mainly due to the small specific surface area. For this reason, the modification of its surface, by molecules having higher fluoride adsorption, has recently been investigated ${ }^{63}$.

Our research aims at the removal of fluoride ions from aqueous solutions through adsorption by the aluminum-based adsorbent. The investigations were focused on the dynamic adsorption behavior of fluoride on the surface of the adsorbent, including isotherms studies and kinetics, in batch experiments. The significant novelty of this study is the simple preparation of a novel aluminum-based adsorbent that increases its affinity for fluorine and its stability in different $\mathrm{pH}$.

\section{Experimental}

\subsection{Materials}

All the chemicals used in the present study were of analytical reagent grade. Aluminum nitrate $\left(\mathrm{Al}\left(\mathrm{NO}_{3}\right)_{3}, 9 \mathrm{H}_{2} \mathrm{O}\right)$, hydrochloric acid $(\mathrm{HCl})$, sodium fluoride $(\mathrm{NaF})$, hydrochloric acid $(\mathrm{HCl})$, caustic soda $(\mathrm{NaOH})$ and TISAB III were purchased from Merck.

\subsection{Preparation of adsorbent}

Aluminum-based particles are synthesized by precipitation method ${ }^{64}$. Aluminum nitrate and sodium hydroxide as the basic raw material were used for the process. The uniform aluminum solution was prepared by dissolving 375,13 g aluminum nitrate $\left(\mathrm{Al}\left(\mathrm{NO}_{3}\right)_{3}, 9 \mathrm{H}_{2} \mathrm{O}\right)$ into deionized water. Then, $800 \mathrm{~mL}$ of a $5 \mathrm{M} \mathrm{NaOH}$ solution was added. The aluminum nitrate reacted with sodium hydroxide, at room temperature, in a ratio of 1:4. The nucleophilic substitution of the $\mathrm{OH}$ group makes it possible to prepare $\mathrm{Al}(\mathrm{OH})_{4}$ with sodium nitrate and water. The obtained precipitate was filtered and dried in a draught drying cabinet at $105^{\circ} \mathrm{C}$ for $12 \mathrm{~h}$. The obtained powder was ground, sieved through $1 \mathrm{~mm}$ sieve, and then calcined in a muffle furnace at $750^{\circ} \mathrm{C}$ for $4 \mathrm{~h}$ in the presence of air at a heating rate of $10^{\circ} \mathrm{C} \cdot \mathrm{min}^{-1}$. The theoretical equations for the adsorbent synthesis can be written as Eqs. 1 and 2 64 .

$$
\begin{aligned}
& \mathrm{Al}\left(\mathrm{NO}_{3}\right)_{3}, 9 \mathrm{H}_{2} \mathrm{O}+4 \mathrm{NaOH} \rightarrow \mathrm{Na}\left(\mathrm{Al}(\mathrm{OH})_{4}\right)+3 \mathrm{NaNO}_{3}+9 \mathrm{H}_{2} \mathrm{O} \\
& \mathrm{Na}\left(\mathrm{Al}(\mathrm{OH})_{4}\right) \rightarrow \mathrm{Na}\left(\mathrm{AlO}_{2}\right)+2 \mathrm{H}_{2} \mathrm{O}
\end{aligned}
$$

\subsection{Characterization of adsorbent}

An accurate structural and morphological characterization of adsorbent was determined by X-Ray Diffraction (XRD X'Pert PRO Panalatycal) and X-Ray Fluorescence (XRF, Oxfordmdx 1000). The Specific Surface Area was determined by the BET method using nitrogen adsorption (SSAN2BET) (Flowsorb II 2300, Micromeritics). Energy Dispersive X-ray attached to Scanning Electron Microscopy (SEM-EDX) was used to observe the morphological features of synthetic adsorbent and to determine the spot element analysis of these latter. The functional groups present in adsorbent were determined by FT-IR using a Fourier Transform Infrared spectrophotometer, (Model Bruker Vertex 70. FTIR) spectra were recorded between $4000 \mathrm{~cm}^{-1}$ and $\quad 400 \mathrm{~cm}^{-1}$.

\subsection{Fluoride solutions preparation and instrumental analysis}

Sodium fluoride $(\mathrm{NaF})$ was used during adsorption experiments as the source of $\mathrm{F}^{-}$. A stock solution of $100 \mathrm{mg} \mathrm{L}^{-1} \mathrm{~F}^{-}$was prepared by dissolving $221 \mathrm{mg}$ of
$\mathrm{NaF}$ in $1000 \mathrm{~mL}$ of deionized water. Experimental solutions for various experiments were then prepared by appropriate dilution of the stock solution. $\mathrm{F}^{-}$concentration was measured by the potentiometric method ${ }^{65}$ with a fluoride-specific ion electrode (WTW F800 Fluoride Combination Electrode) connected to a digital ion analyzer (WTW InoLab $\mathrm{pH} / \mathrm{Ion}$ 7320). The use of Total Ionic Strength Adjustment Buffer III (TISAB III) ${ }^{66}$ was for maintaining the ionic strength $\mathrm{pH}$ constant to decomplex Metal-F complexes present in the sample during the measurement (NF $\mathrm{T}$ 90-004). All adsorption experiments were conducted at room temperature of $25 \pm 2^{\circ} \mathrm{C}$.

\subsection{Batch adsorption experiments}

The batch experiments consisted analysing the effect of controlling parameters such as contact time, initial $\mathrm{F}^{-}$concentration, adsorbent dose and initial $\mathrm{pH}$ solution (the $\mathrm{pH}$ adjustment was carried out by using $0.1 \mathrm{~N}(\mathrm{HCl})$ or $0.1 \mathrm{~N}(\mathrm{NaOH}))$ on $\mathrm{F}^{-}$adsorption. All the experiments were conducted at room temperature of $25 \pm 2^{\circ} \mathrm{C}$ in $500 \mathrm{~mL}$ plexiglass reactor. A specific 
amount of adsorbent was added to the fluoride-doped synthetic solution. The reaction mixture was continuously blended by an electric rod stirrer at $350 \mathrm{rpm}$. At equilibrium, the liquid phase is recovered in an Erlenmeyer flask after vacuum filtration through Whatman No. 42 filter paper for $\mathrm{F}^{-}$ analysis, The equilibrium study is performed by varying initial $\mathrm{F}^{-}$concentrations from 20 to $160 \mathrm{mg}$ $\mathrm{L}^{-1}$, while maintaining the constant adsorbent dosage and the contact time at $3 \mathrm{~g} \mathrm{~L}^{-1}$ and $24 \mathrm{~h}$, respectively, for each sample. The effect of adsorbent dosage is studied by varying the mass of adsorbent from 1 to $6 \mathrm{~g} \mathrm{~L}^{-1}$ in a sample of $40 \mathrm{mg} \mathrm{L}^{-1}$ initial $\mathrm{F}^{-}$concentration at natural $\mathrm{pH}(7 \pm 0.2)$. The effect of $\mathrm{pH}$ is also studied by conducting experiments for a variation of $\mathrm{pH}$ from 3 to 11 by keeping the initial $\mathrm{F}^{-}$concentration and the adsorbent dose at $40 \mathrm{mg} \mathrm{L}^{-1}$ and $3 \mathrm{~g} \mathrm{~L}^{-1}$, respectively.

\subsection{Fluoride removal calculation}

The specific amount of the adsorbed $\mathrm{F}^{-}, Q_{\mathrm{e}}\left(\mathrm{mg} \mathrm{g}^{-1}\right)$, was calculated according to Eq. (3):

$Q_{\mathrm{e}}=\frac{C_{0}-C_{\mathrm{e}}}{W} \times V$

Where, $Q_{\mathrm{e}}$ is the adsorption capacity $\left(\mathrm{mg} \mathrm{g}^{-1}\right)$ in the solid at equilibrium; $C_{\mathrm{o}}, C_{\mathrm{e}}$ are initial and equilibrium concentrations of $\mathrm{F}^{-} \quad\left(\mathrm{mg} \quad \mathrm{L}^{-1}\right)$, respectively; $V$ is the volume of the aqueous solution (L) and $W$ is the mass (g) of adsorbent used in the experiments.

The adsorption removal efficiency (ARE), at equilibrium, was calculated by using Eq. (4):

$A R E(\%)=\frac{C_{0}-C_{\mathrm{e}}}{C_{0}} \times 100$

\subsection{Modeling studies}

\subsubsection{Kinetic models}

The pseudo-first-order is a kinetic model described by the following Lagergren Eq. (5) ${ }^{67}$ :

$\frac{d Q_{\mathrm{t}}}{\mathrm{d} t}=K_{1}\left(Q_{\mathrm{e}}-Q_{\mathrm{t}}\right)$

The linear form of pseudo-first order kinetic model can be expressed by Eq. (6):

$\log \left(Q_{\mathrm{e}}-Q_{\mathrm{t}}\right)=\log Q_{\mathrm{e}}-\left(\frac{K_{1}}{2.3}\right) t$

Where, $Q_{\mathrm{e}}$ and $Q_{\mathrm{t}}$ are the amount of $\mathrm{F}^{-}$adsorbed $\left(\mathrm{mg} \mathrm{g}^{-1}\right)$ at equilibrium and at a time ' $t$ ', respectively. $K_{1}\left(\min ^{-1}\right)$ represents the rate constant of pseudofirst-order adsorption reaction. A straight line of $\log \left(Q_{\mathrm{e}}-Q_{\mathrm{t}}\right)$ against $t$ suggests the applicability of these kinetic models. Both $Q_{\mathrm{e}}$ and $K_{1}$ can be determined from the intercept and slope of the curve, respectively.

The linear form of the pseudo-second-order kinetic model can be expressed by Eq. (7) ${ }^{68}$ :

$\frac{t}{Q_{\mathrm{t}}}=\left(\frac{1}{K_{2} \times Q_{e}^{2}}\right)+\frac{t}{Q_{\mathrm{e}}}$

where $K_{2}$ is the rate constant for pseudo-secondorder reaction $\left(\mathrm{g} \mathrm{mg}^{-1} \mathrm{~min}^{-1}\right) . Q_{\mathrm{e}}$ and $Q_{\mathrm{t}}$ are the amounts of $\mathrm{F}^{-}$adsorbed at equilibrium and at any time ' $t$ ' $\left(\mathrm{mg} \mathrm{g}^{-1}\right)$, respectively. The straight-line plot of $t / Q_{\mathrm{t}}$ against $t$ for the kinetic data gives the values for $Q_{\mathrm{e}}$ and $K_{2}$ from the slope and intercept, respectively.

\subsection{2.. Adsorption isotherms}

The isotherm equations Langmuir and Freundlich isotherm models have been used in the present study, to describe the equilibrium data. The Langmuir equation can be described in the following Eq. (8) ${ }^{69}$ :

$Q_{\mathrm{e}}=\frac{Q_{\mathrm{m}} \times K_{\mathrm{L}} \times C_{\mathrm{e}}}{1+\left(K_{\mathrm{L}} \times C_{\mathrm{e}}\right)}$

The linearized form of Eq. (6) can be written as Eq. (9):

$\frac{1}{Q_{\mathrm{e}}}=\left(\frac{1}{Q_{\mathrm{m}} \times K_{\mathrm{L}}}\right)\left(\frac{1}{C_{\mathrm{e}}}\right)+\frac{1}{Q_{\mathrm{m}}}$

where $C_{\mathrm{e}}$ is the equilibrium concentration of fluoride ions $\left(\mathrm{mg} \mathrm{L}^{-1}\right), Q_{\mathrm{e}}$ is a solid phase concentration of fluoride ions $\left(\mathrm{mg} \mathrm{g}^{-1}\right), Q_{\mathrm{m}}\left(\mathrm{mg} \mathrm{g}^{-1}\right)$, and $K_{\mathrm{L}}\left(\mathrm{L} \mathrm{mg}^{-1}\right)$ are empirical constants, can be evaluated from the slope and intercept of the linear plot of $1 / Q_{\mathrm{e}}$ against $1 / C_{\mathrm{e}}$.

The Freundlich is expressed mathematically in linear form as it is represented in Eq. (10) ${ }^{70}$ :

$$
\log Q_{\mathrm{e}}=\log K_{\mathrm{F}}+\frac{1}{n} \log C_{\mathrm{e}}
$$

Where, $K_{\mathrm{F}}\left(\mathrm{mg} \mathrm{g}^{-1}\right)$ and $1 / n$ are Freundlich constants related to adsorption capacity and adsorption intensity, respectively. Those constants are obtained from the intercept and slope of $\log Q_{\mathrm{e}}$ versus $\log C_{\mathrm{e}}$ linear plot, respectively.

\section{Results and discussion}

\subsection{Characterization of adsorbent}

\subsubsection{X-Ray Diffraction (XRD) analysis}

The structural characterization of synthetic adsorbent was carried out by X-Ray Diffraction (XRD) as shown in Figure 1. XRD pattern of adsorbent showed three major well-crystallized phases (sodium nitrate $\left(\mathrm{NaNO}_{3}\right)$, sodium aluminum oxide $\left(\mathrm{Na}\left(\mathrm{AlO}_{2}\right)\right)$ and sodium carbonate $\left.\left(\mathrm{Na}_{2} \mathrm{CO}_{3}\right)\right)$ with well-resolved peaks. 


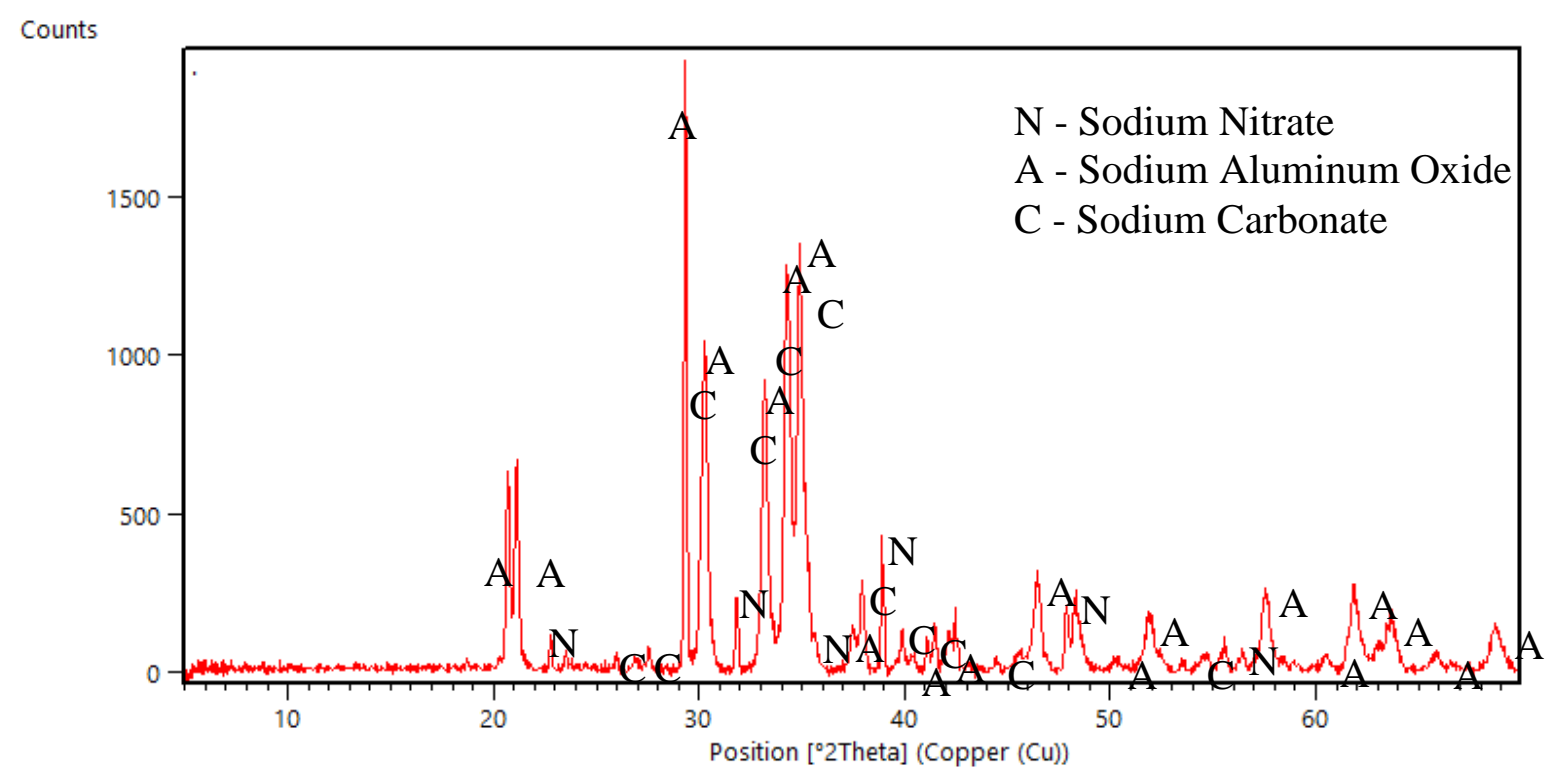

Figure 1. XRD patterns of adsorbent

3.1.2. X-Ray Fluorescence (XRF) analysis

The chemical constituents of adsorbent are shown in Table 1 . The analysis revealed that alumina $\left(\mathrm{Al}_{2} \mathrm{O}_{3}\right)$ was the main component at $44.97 \%$, followed by sodium oxide $\left(\mathrm{Na}_{2} \mathrm{O}\right)$ at $9.45 \%$, confirming that synthetic adsorbent is based on sodium aluminum oxide.

Table 1. Elemental composition of the adsorbent.

\begin{tabular}{|c|c|c|}
\hline Element & Content & Unit \\
\hline $\mathrm{Al}_{2} \mathrm{O}_{3}$ & 44.97 & \multirow{6}{*}{$\%$} \\
\hline $\mathrm{Na}_{2} \mathrm{O}$ & 9.45 & \\
\hline $\mathbf{P}_{2} \mathrm{O}_{5}$ & 0.35 & \\
\hline $\mathrm{SiO}_{2}$ & 0.27 & \\
\hline $\mathrm{CaO}$ & 0.13 & \\
\hline $\mathrm{K}_{2} \mathrm{O}$ & 0.12 & \\
\hline $\mathrm{Fe}_{2} \mathrm{O}_{3}$ & 533.5 & \multirow{11}{*}{ ppm } \\
\hline $\mathrm{Cr}_{2} \mathrm{O}_{3}$ & 183.5 & \\
\hline $\mathrm{Cl}$ & 108.8 & \\
\hline $\mathrm{Ga}_{2} \mathrm{O}_{3}$ & 20.1 & \\
\hline $\mathrm{NiO}$ & 15.6 & \\
\hline ZnO & 6.8 & \\
\hline $\mathrm{CuO}$ & 6.1 & \\
\hline $\mathrm{Rb}_{2} \mathrm{O}$ & 3.1 & \\
\hline $\mathrm{Yb}_{2} \mathrm{O}_{3}$ & 0.6 & \\
\hline $\mathbf{R e}$ & 0.5 & \\
\hline $\mathrm{IrO}_{2}$ & 0.1 & \\
\hline
\end{tabular}

3.1.3. Energy Dispersive X-ray attached to Scanning Electron Microscopy (SEM-EDX) analysis
The results of SEM-EDX analysis of synthetic adsorbent are presented in Figures 2, 3. The SEM pictures showed surface morphology and grain distribution. 

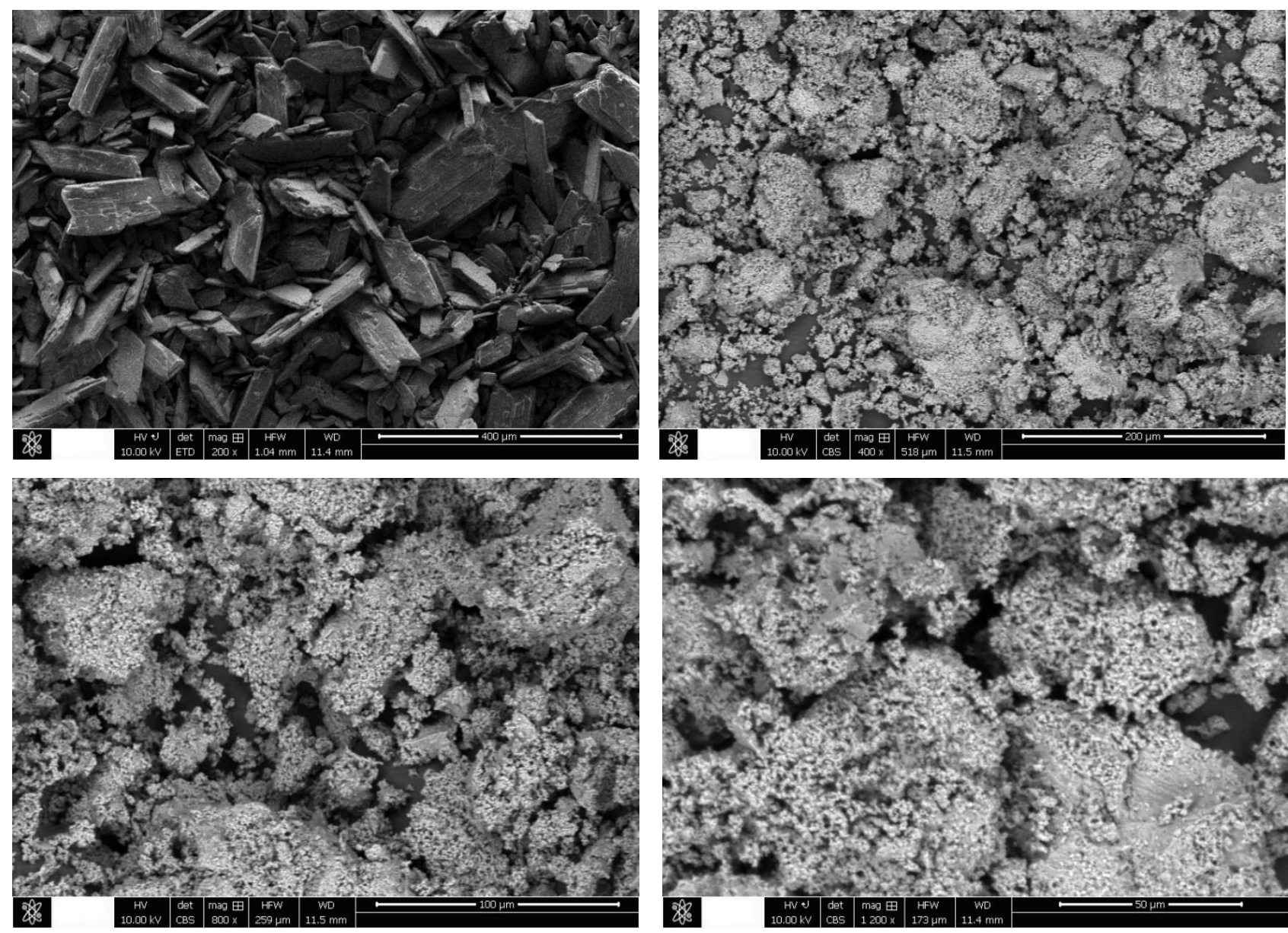

Figure 2. SEM of adsorbent

Figure 2 showed the pictures that were obtained by applying a voltage of $10 \mathrm{KV}$ with different magnifications. The surface has a cloudy appearance and regular shape with bright white particles probably of aluminium, displaying a cylindrical rod as a structure with different particles size ${ }^{41}$.
The EDX spectrum implied that the composite is made up of uniformly distributed carbon, oxygen, sodium and aluminum all over the surface as shown in Figure 3.

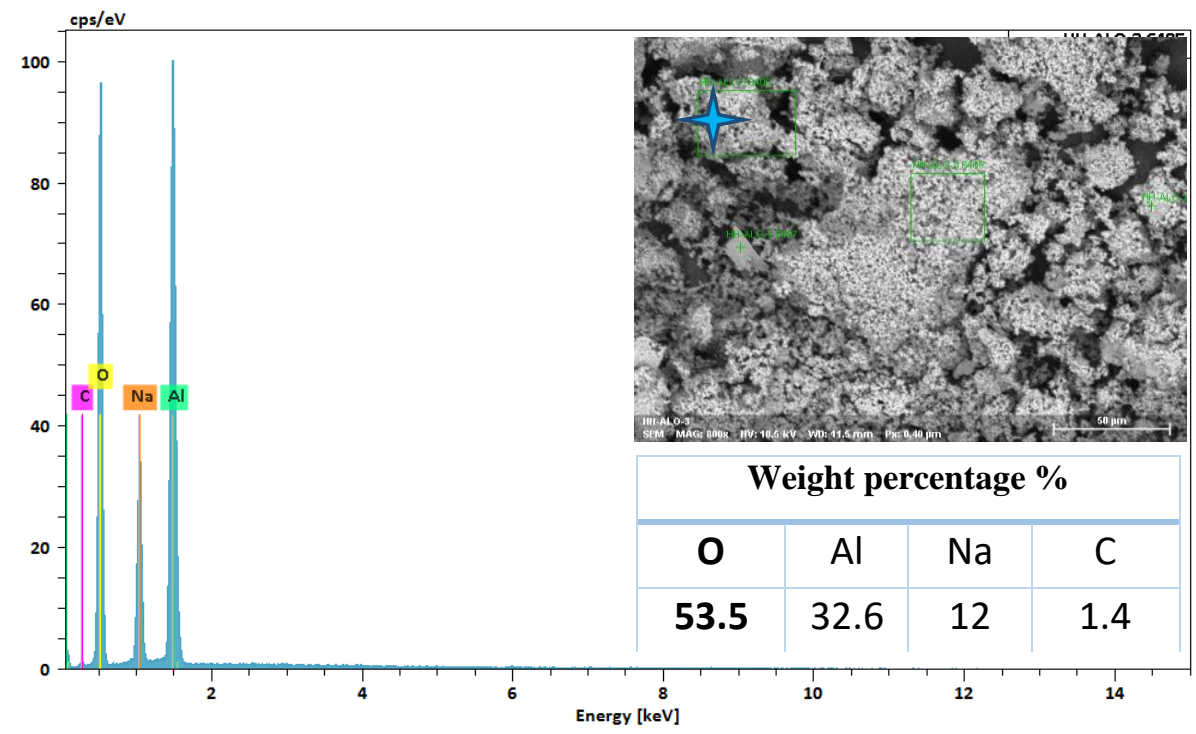

Figure 3. SEM-EDX of the adsorbent 


\subsubsection{BET Specific Surface Area (SSAN2BET)} analysis

The BET results show that the aluminum basedadsorbent presents an important surface area $\left(\simeq 10.0059 \mathrm{~m}^{2} \mathrm{~g}^{-1}\right)$ comparing to most of the activated alumina adsorbents with some exceptions.

\subsubsection{Fourier-Transform Infrared Spectrometry (FTIR) analysis}

The FTIR spectra of the aluminous support, before and after adsorption (Figure 3), showed common bands corresponding to the basic structure $\left(\mathrm{AlO}_{2}\right)$ such as two bands at $1371 \mathrm{~cm}^{-1}$ and $1236 \mathrm{~cm}^{-1}$ which most probably correspond to the symmetrical and antisymmetric elongation of $\mathrm{Al}=\mathrm{O}$ group.
Furthermore, two bands at $966 \mathrm{~cm}^{-1}$ and $511 \mathrm{~cm}^{-1}$ correspondings to the deformations of the group $\mathrm{Al}=\mathrm{O}{ }^{71}$. While the appearance of two bands at $1742 \mathrm{~cm}^{-1}$ and $3428 \mathrm{~cm}^{-1}$ are characteristic of the $\mathrm{OH}$ group of the $\mathrm{H}_{2} \mathrm{O}$ molecule. The comparison of the FTIR spectra did not show any difference between the infrared spectra of the adsorbent $(\mathrm{Na}$ $\left(\mathrm{AlO}_{2}\right)$ ) before and after the adsorption tests. Nevertheless, if we look carefully (the spectrum in blue), we can notice that there is an appearance of small bands at $507.58 \mathrm{~cm}^{-1}$ and $554.94 \mathrm{~cm}^{-1}$ correspondings to the Al-F bond ${ }^{72}$, which confirms the adsorption of $\mathrm{F}^{-}$ions by our adsorbent through a chemisorption mechanism.

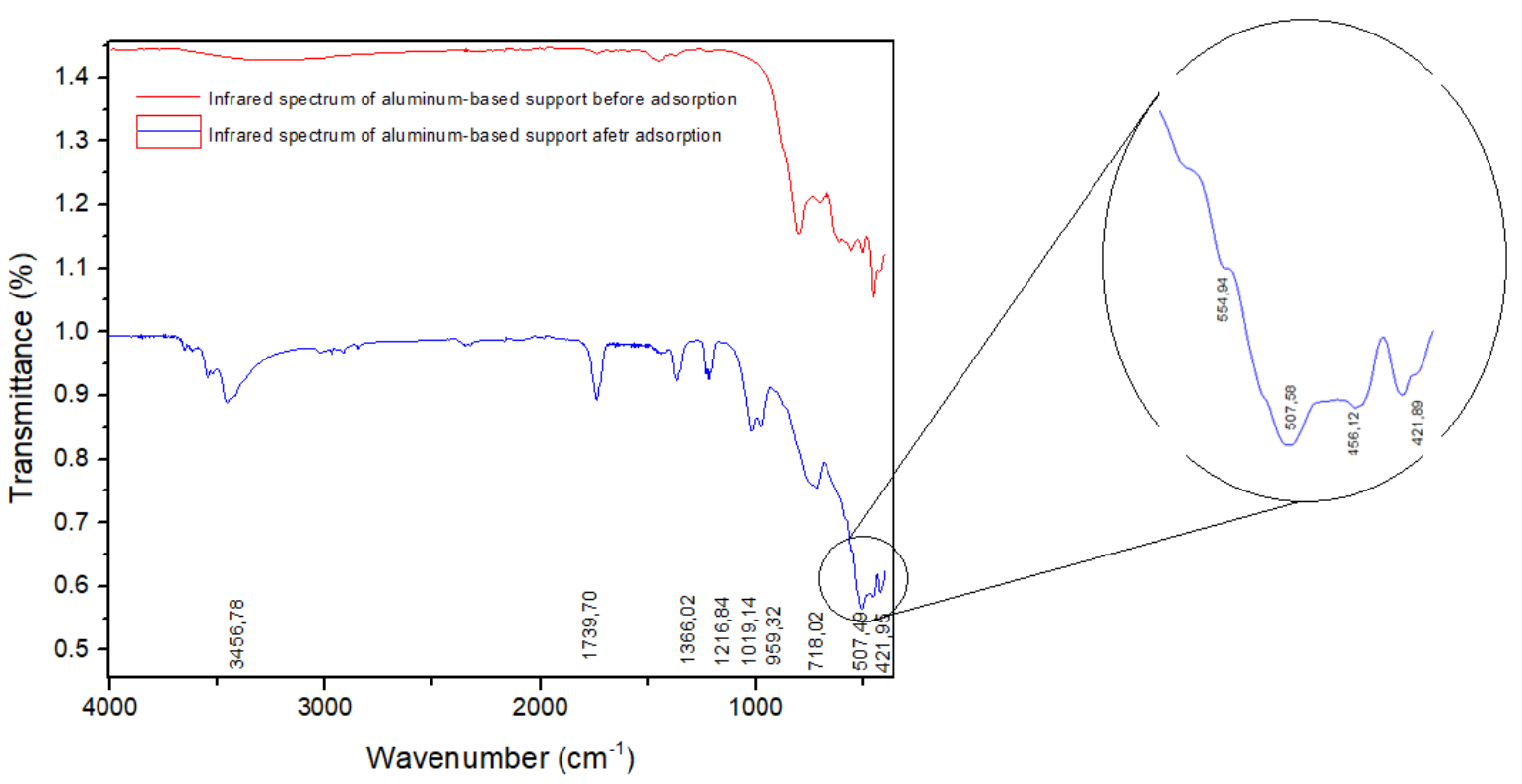

Figure 3. FTIR spectra of adsorbent and the fluoride adsorbed

\subsection{Batch experiments results}

\subsubsection{The effect of contact time}

The effect of contact time on the percentage of $\mathrm{F}^{-}$ adsorbed was investigated to ensure equilibrium state between aqueous $\mathrm{F}^{-}$and the adsorbent.

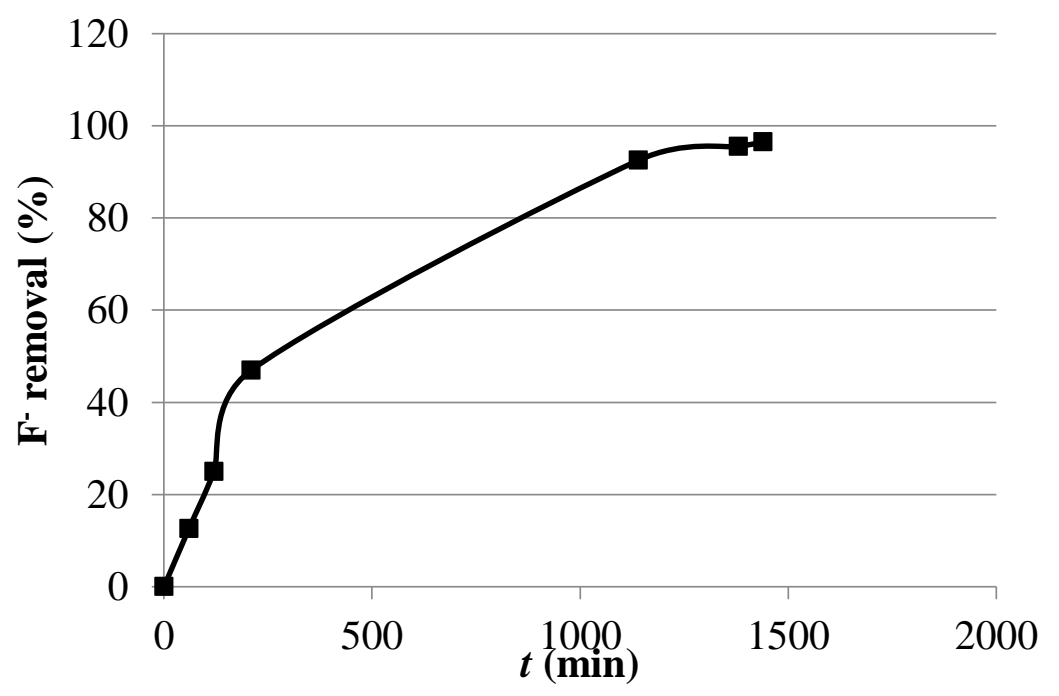

Figure 4. Effect of contact time on the percentage of Fremoval (\%) 
Figure 4 shows the progression of adsorption reaction, the percentage of the $\mathrm{F}^{-}$adsorbed on to the adsorbent after different contact times. It was observed that with a fixed amount of the adsorbent, the percentage of $\mathrm{F}^{-}$adsorbed increased with contact time and began to reach equilibrium after $24 \mathrm{~h}$ of reaction. Consequently, the contact time fixed for further adsorption experiments was $24 \mathrm{~h}$.

\subsubsection{The effect of initial fluoride concentration}

The effect of initial concentration on the percentage of $\mathrm{F}^{-}$removal was carried out to determine the maximum adsorption capacity of the synthetic adsorbent. The adsorbent dose and initial $\mathrm{pH}$ solution were fixed at $3 \mathrm{~g} \mathrm{~L}^{-1}$ and $7 \pm 0.2$, respectively. As shown in Figure 5, the adsorption capacity reached stability at a high initial concentration $\left(100 \mathrm{mg} \mathrm{L}^{-1}\right)$. This can be explained by saturation of the available active adsorption sites. Though, the percentage of $\mathrm{F}^{-}$ removal decreased with an increase in the initial concentration. This decrease is due to the presence of more $\mathrm{F}^{-}$ion in solution at higher initial $\mathrm{F}^{-}$ concentration. However, the efficient $\mathrm{F}^{-}$removal at a low initial concentration was because of the important ratio of surface active sites to total $\mathrm{F}^{-}$ions present in solution.

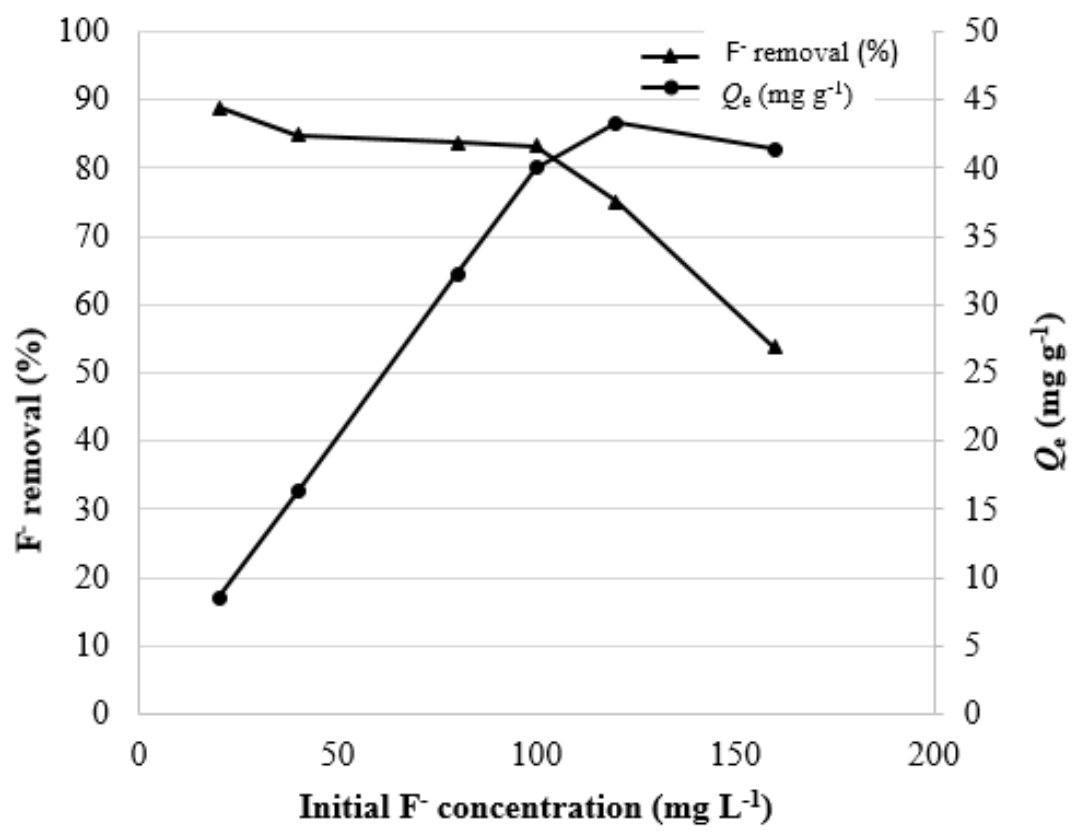

Figure 5. Fremoval and adsorption capacity against initial $\mathrm{F}^{-}$concentration $(\mathrm{pH}=7 \pm 0.2$, contact time $=24 \mathrm{~h}$, adsorbent dose $=3 \mathrm{~g} \mathrm{~L}^{-1}$, agitation speed $\left.=350 \mathrm{rpm}, \mathrm{T}=25 \pm 2^{\circ} \mathrm{C}\right)$

\subsubsection{The effect of adsorbent dose}

Figure 6 shows that the percentage of Fremoval increased slightly with increasing adsorbent dose up to $3 \mathrm{~g} \mathrm{~L}^{-1}$. The increase of percent $\mathrm{F}^{-}$removal with the increase of the adsorbent dose is due to the availability of sufficient adsorption sites. However, the addition of the adsorbent dose did not show any considerable increase in the percentage of Fremoval. This may be probably due to the overlapping phenomenon of the active sites at a higher adsorbent dose resulting in a reduction of surface area ${ }^{73}$.

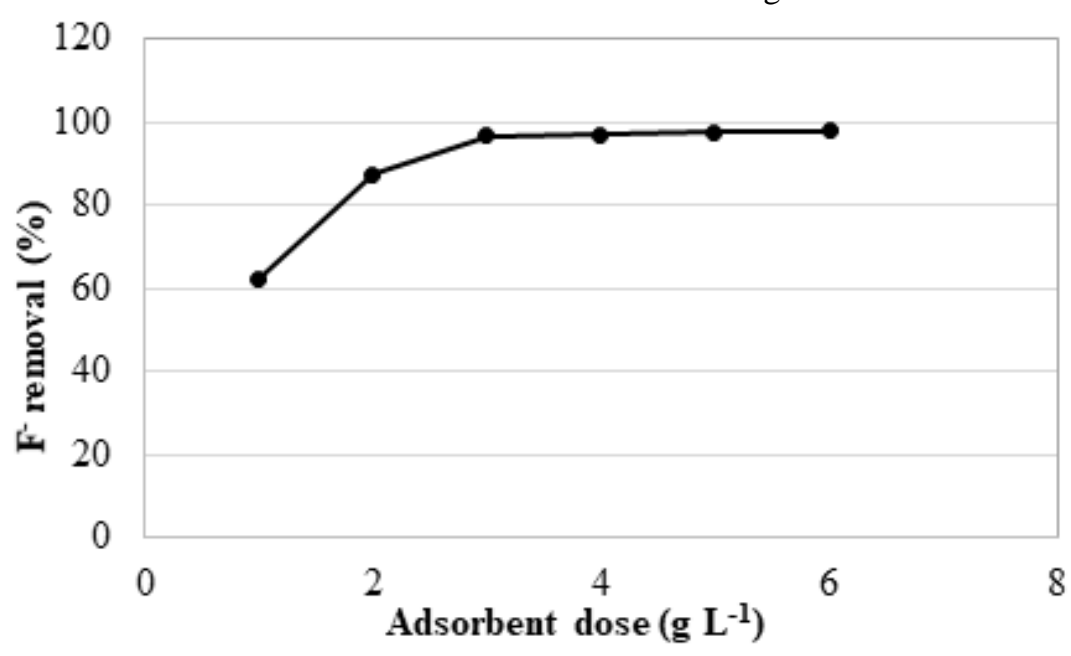

Figure 6. Effect of adsorbent dose on percentage of $\mathrm{F}^{-}$removal (natural $\mathrm{pH}=7 \pm 0.2$, initial $\mathrm{F}^{-}$concentration $=40$ $\mathrm{mg} \mathrm{L}^{-1}$, contact time $=24 \mathrm{~h}$, agitation speed $=350 \mathrm{rpm}, \mathrm{T}=25 \pm 2^{\circ} \mathrm{C}$ ) 


\subsubsection{The effect of initial $\mathrm{pH}$ solution and determination of $\mathbf{p H} \mathrm{PZC}$}

Figure 7 illustrates the evolution of the percentage of $\mathrm{F}^{-}$removal over the $\mathrm{pH}$ range of $3-11$. It was observed that the percentage of $\mathrm{F}^{-}$removal does not weaken in the full $\mathrm{pH}$ range of 3 to 11 . The adsorption of the $\mathrm{F}^{-}$ions on the synthetic adsorbent is thus not dependent on $\mathrm{pH}$. It is therefore not simple physisorption, and there is probably an appreciable contribution of chemisorption, resulting in a partial formation of aluminum fluoride and sodium fluoride under acidic and alkaline conditions ${ }^{74}$.

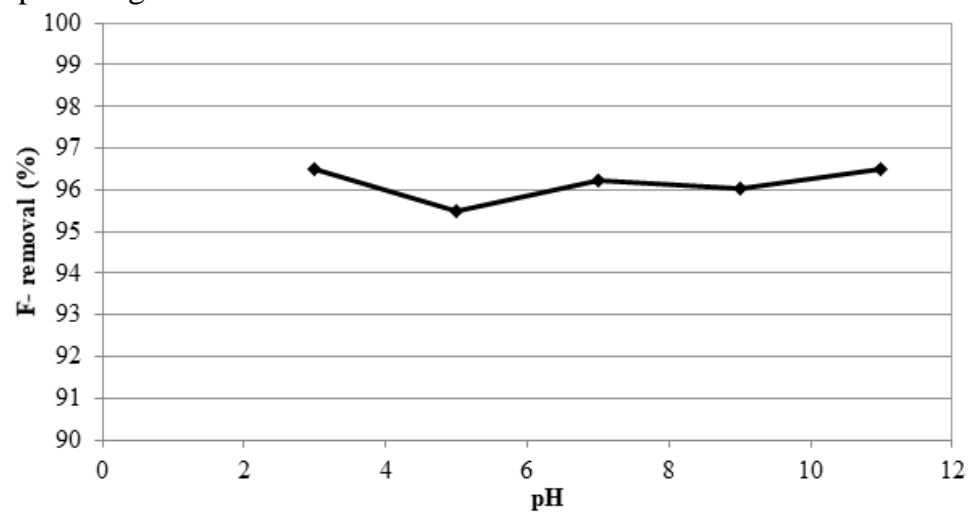

Figure 7. Effect of $\mathrm{pH}$ on percentage of $\mathrm{F}^{-}$removal (adsorbent dose $=3 \mathrm{~g} \mathrm{~L}^{-1}$, initial $\mathrm{F}^{-}$concentration $=40 \mathrm{mg} \mathrm{L}^{-1}$, contact time $=24 \mathrm{~h}$, agitation speed $=350 \mathrm{rpm}, \mathrm{T}=25 \pm 2^{\circ} \mathrm{C}$ ).

The point of zero charge ( $\left.\mathrm{pH}_{\mathrm{PZC}}\right)$ plays a crucial role in determining the optimal $\mathrm{pH}$ of the solution where the fluoride adsorption is favored. The adsorption of these anions becomes favorable when the adsorbent surface is positively charged at a particular $\mathrm{pH}$ (i.e. $\mathrm{pH}_{\text {solution }}<\mathrm{pH}_{\mathrm{PZC}}$ ) ${ }^{75}$. The $\mathrm{PZC}$ of the aluminum-based adsorbent was measured using the powder addition method ${ }^{75}$, by adding $20 \mathrm{~mL}$ of $510^{-2}$ mol. $\mathrm{L}^{-1} \mathrm{NaCl}$ to several $50 \mathrm{~mL}$ cylindrical high-density polystyrene flasks. A range of initial $\mathrm{pH}\left(\mathrm{pH}_{\mathrm{i}}\right)$ values of the $\mathrm{NaCl}$ solutions was adjusted from 2 to 12 by adding $10^{-1}$ mol. $\mathrm{L}^{-1}$ of $\mathrm{HCl}$ and $\mathrm{NaOH}$. The total volume of the solution in each flask was brought to exactly $30 \mathrm{~mL}$ by further addition of $510^{-2}$ mol. $\mathrm{L}^{-1} \mathrm{NaCl}$ solution. The $\mathrm{pH}_{\mathrm{i}}$ values of the solutions were then accurately noted and $50 \mathrm{mg}$ of the adsorbent was added to each flask, which was securely capped. The suspensions were shaken in a shaker at $298 \mathrm{~K}$ and allowed to equilibrate for $48 \mathrm{~h}$. The suspensions were then centrifuged at $3600 \mathrm{rpm}$ for $15 \mathrm{~min}$ and the final $\mathrm{pH}$ $\left(\mathrm{pH}_{\mathrm{f}}\right)$ values of the supernatant liquid were recorded. The value of $\mathrm{pH} P \mathrm{PZC}$ is the point where the curve of $\Delta \mathrm{pH}\left(\mathrm{pH}_{\mathrm{f}}-\mathrm{pH}_{\mathrm{i}}\right)$ versus $\mathrm{pH}_{\mathrm{i}}$ crosses the line equal to zero ${ }^{76}$. The obtained results are presented in Figure 8. These results show clearly that the PZC of aluminum-based adsorbent is outside a $\mathrm{pH}$ range of 2 to 12 because there is no intersection of the curve with the $\mathrm{x}$-axis. Therefore, it can be concluded that the $\mathrm{pH}$ does not affect the adsorption phenomena by the aluminum-based adsorbent. This result confirms our experimental results and the $\mathrm{pH}$ will be no change the adsorbent capacity of the aluminum-based adsorbent.

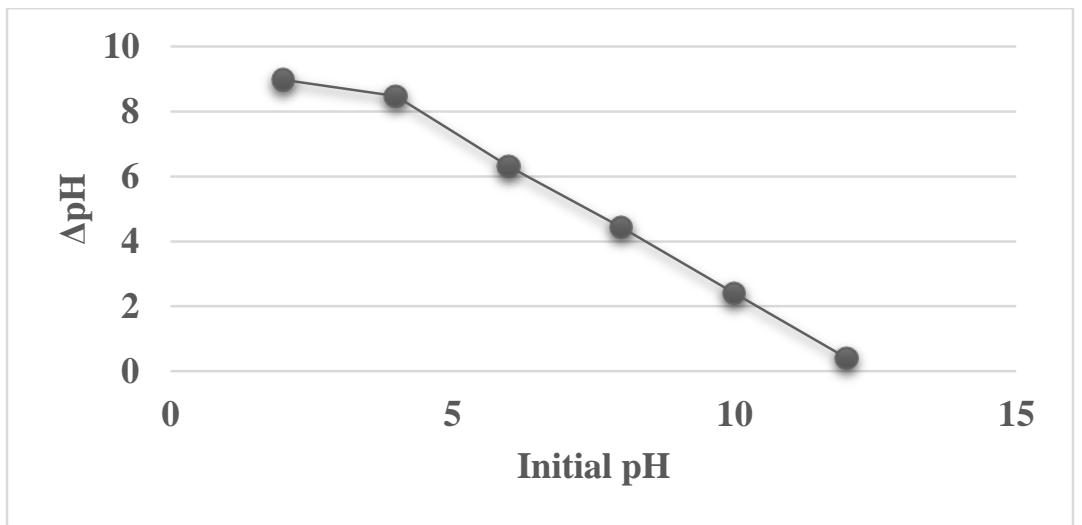

Figure 8. The determination of the point of zero charge ( $\left.\mathrm{PH}_{\mathrm{PZC}}\right)$ using $0.05 \mathrm{M} \mathrm{NaCl}$ solutions (drift method).

\subsection{Kinetic studies}

Several models are exploited to fit the kinetic sorption tests ${ }^{73}$. In this study, the two models (pseudo-first-order and pseudo-second-order) were used to investigate the kinetics of the $\mathrm{F}^{-}$adsorption onto aluminum-base adsorbent, in order to understand the mechanism and the rate-controlling steps affecting the adsorption kinetics. As shown in Figure 9 and 10, the pseudo-first-order (Figure 9) has a very low correlation coefficient $\left(R^{2}=0.7681\right)$. Contrariwise, the pseudo-second-order (Figure 10) was found to give the best fit $\left(R^{2}=0.9911\right)$ 




Figure 9. The adsorption kinetics of the fluoride ions on aluminum-based adsorbent according to the pseudofirst-order kinetic model.



Figure 10. The adsorption kinetics of the fluoride ions on aluminum-based adsorbent according to the pseudo second-order kinetic model

\subsection{Adsorption isotherm}

The adsorption capacity $Q_{\mathrm{e}}\left(\mathrm{mg} \mathrm{g}^{-1}\right)$ of adsorbent was examined by determining the equilibrium sorption of $\mathrm{F}^{-}$as a function of residual $\mathrm{F}^{-}$concentration present in the liquid phase. The variation of the adsorption capacity of adsorbent for $\mathrm{F}^{-}$is presented in Figure 11. According to the equilibrium curve, the adsorption capacity at equilibrium increases progressively at lower $\mathrm{F}^{-}$concentration. This is because of the availability of excess adsorption sites. On the other hand, as the $\mathrm{F}^{-}$concentration increases, the adsorption capacity at equilibrium progressively decreases until reaching saturation. The availability of adsorption sites at high $\mathrm{F}^{-}$concentration becomes the limiting factor as the adsorbent surface reaches maximum adsorption capacity. This latter was observed to be $43.29 \mathrm{mg} \mathrm{g}^{-1}$.

The value of the maximum adsorption capacity obtained for this study in comparison with those reported earlier for adsorption of $\mathrm{F}^{-}$onto various adsorbents (Table 2) revealed that this aluminumbased adsorbent is an active adsorbent in removing fluoride. 




Figure11. Adsorption isotherm of $\mathrm{F}^{-}$sorption (adsorbent dose $=3 \mathrm{~g} \mathrm{~L}^{-1}$, natural $\mathrm{pH}=7 \pm 0.2$, contact time $=24 \mathrm{~h}$, initial concentration $=20-160 \mathrm{mg} \mathrm{L}^{-1}$, agitation speed $=350 \mathrm{rpm}, \mathrm{T}=25 \pm 2^{\circ} \mathrm{C}$ )

Table 3. Comparison of the maximum adsorption capacity of $\mathrm{F}^{-}$with different adsorbents.

\begin{tabular}{|c|c|c|}
\hline Adsorbent & $\boldsymbol{Q}_{\mathbf{e}}\left(\mathbf{m g ~ g}^{-\mathbf{1}}\right)$ & Reference \\
\hline $\begin{array}{c}\mathbf{A l}^{\mathbf{3 +}} \text { pretreated } \\
\text { low-silica synthetic zeolites } \\
\text { Hardened alumina cement }\end{array}$ & $28.21-41.35$ & 77 \\
\hline $\begin{array}{c}\text { Zirconium impregnated } \\
\text { coconut fiber carbon }\end{array}$ & 34.36 & 79 \\
\hline $\begin{array}{c}\text { Aluminum-Impregnated } \\
\text { chitosan Biopolymer }\end{array}$ & 40.016 & 80 \\
\hline Nano-alumina & 1.73 & 81 \\
\hline $\begin{array}{c}\text { Aluminium hydroxide } \\
\text { impregnated macroreticular }\end{array}$ & 14 & 82 \\
\hline \begin{tabular}{c} 
Aluminum-based adsorbent \\
\hline
\end{tabular} & $\mathbf{4 3 . 2 9}$ & This study \\
\hline
\end{tabular}

The equilibrium data were further processed using Langmuir and Freundlich isotherms. The Langmuir model is based on the hypothesis that uptake occurs on a homogenous surface by monolayer adsorption without interaction between adsorbed molecules. While the Freundlich model proposes multilayer adsorption with a heterogeneous energetic distribution of active sites and with the interaction between adsorbed molecules. The Langmuir and Freundlich adsorption isotherms for the $\mathrm{F}^{-}$adsorption are presented in Figure 12.

Langmuir and Freundlich adsorption isotherm constants are indicated in Table 3. 

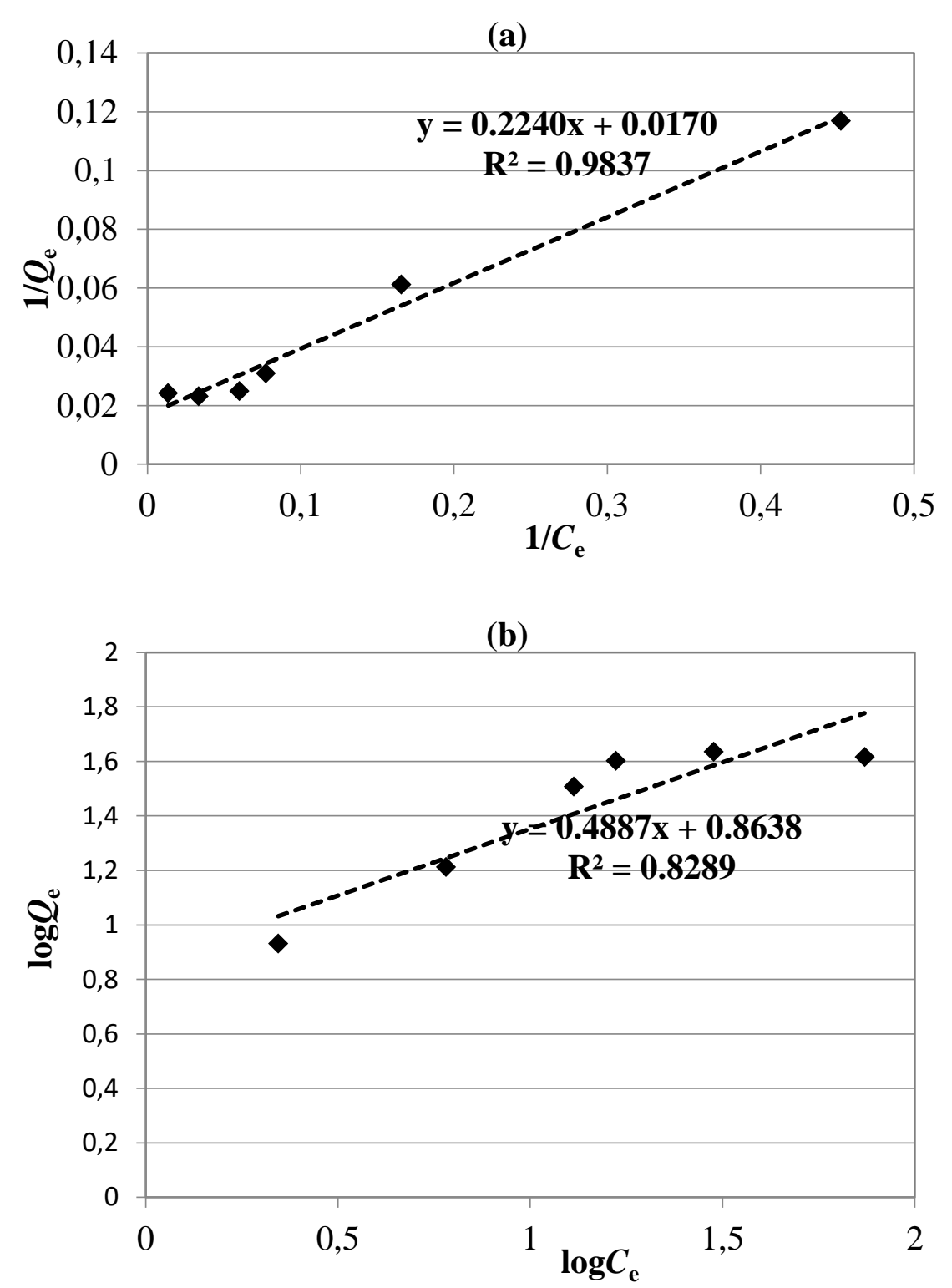

Figure 12. Langmuir (a) and Freundlich (b) isotherm plots for $\mathrm{F}^{-}$adsorption (adsorbent dose $=3 \mathrm{~g} \mathrm{~L}^{-1}$, natural $\mathrm{pH}=7 \pm 0.2$, contact time $=24 \mathrm{~h}$, initial $\mathrm{F}^{-}$concentration $=20-160 \mathrm{mg} \mathrm{L}^{-1}$, agitation speed $=350 \mathrm{rpm}$, $\mathrm{T}=25 \pm 2^{\circ} \mathrm{C}$ )

Table 3. Langmuir and Freundlich adsorption isotherm constants.

\begin{tabular}{|c|c|c|c|c|c|}
\hline \multicolumn{3}{|c|}{ Langmuir } & \multicolumn{3}{c|}{ Freundlich } \\
\hline $\boldsymbol{Q}_{\mathbf{m}}\left(\mathbf{m g ~ g}^{\mathbf{- 1}}\right)$ & $\boldsymbol{K}_{\mathbf{L}}\left(\mathbf{L ~ m g ~}^{\mathbf{- 1}}\right)$ & $\boldsymbol{R}^{\mathbf{2}}$ & $\boldsymbol{n}$ & $\boldsymbol{K F}_{\mathbf{F}}$ & $\boldsymbol{R}^{\mathbf{2}}$ \\
\hline $\mathbf{5 8 . 8 2}$ & 0.076 & 0.9837 & 2.046 & 0.1368 & 0.8289 \\
\hline
\end{tabular}

The essential features of the Langmuir isotherm can be expressed by the equilibrium parameter $\left(R_{\mathrm{L}}\right)$ which is determined by the Eq. (11) ${ }^{83}$.

$$
R_{L}=\frac{1}{1+K_{L} C_{0}}
$$

Where $C_{0}\left(\mathrm{mg} \mathrm{L}^{-1}\right)$ is the initial concentration of $\mathrm{F}^{-}$ and $K_{\mathrm{L}}\left(\mathrm{L} \mathrm{mg}^{-1}\right)$ is the Langmuir constant related to the energy of adsorption. The value of $R_{\mathrm{L}}$ indicates the shape of the isotherms to be either unfavourable $\left(R_{\mathrm{L}}>1\right)$, linear $\left(R_{\mathrm{L}}=1\right)$, favourable $\left(0<R_{\mathrm{L}}<1\right)$ or irreversible $\left(R_{\mathrm{L}}=0\right)$. The calculated $R_{\mathrm{L}}$ values as different initial fluoride concentrations are shown in Figure 13. It was observed that the value of $R_{\mathrm{L}}$ in the range $0-1$ confirms the favourable adsorption. 


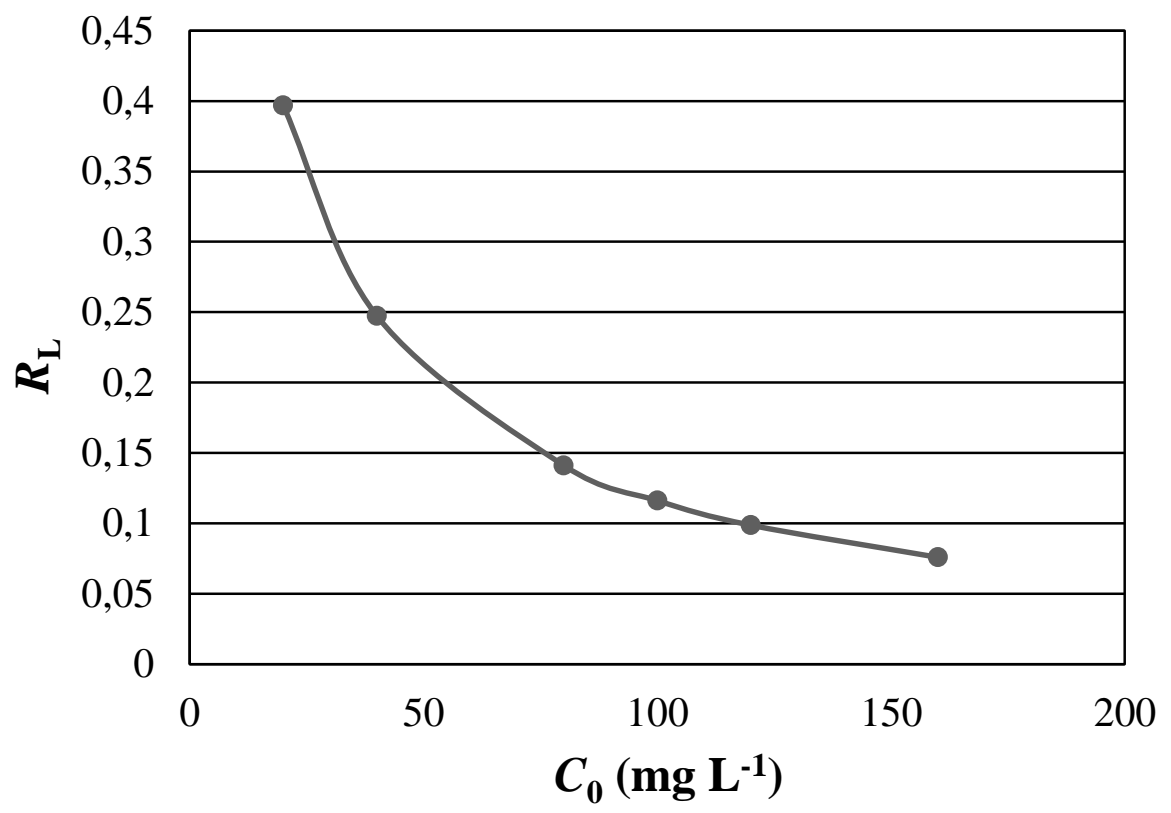

Figure 13. Plot of equilibrium parameter versus initial fluoride concentration.

The favourable adsorption of the Freundlich isotherm can be characterised such that if a value for $n$ is above unity, adsorption is favourable and a physical process. In this study, the value of $n(n=2.046)$ is greater than 1 , indicating that the adsorption is favourable. However, the value of correlation coefficient $\left(R^{2}=0.8289\right)$ is lower than the Langmuir isotherm value (0.9837). Therefore, the $\mathrm{F}^{-}$adsorption onto aluminium-based adsorbent were better described by Langmuir isotherm confirming monolayer adsorption without interaction between adsorbed molecules.

\section{Conclusion}

The defluoridation efficiency of aluminum-based adsorbent was evaluated in a batch adsorption reactor at room temperature $\left(25 \pm 2^{\circ} \mathrm{C}\right)$. The results of the batch adsorption experiments demonstrated that $24 \mathrm{~h}$ of contact time between the adsorbent and the fluoride solution was sufficient to achieve equilibrium. It was observed that the maximum wastewater $(84.91 \%)$ was obtained for $40 \mathrm{mg} \mathrm{L}^{-1}$ and $3 \mathrm{~g} \mathrm{~L}^{-1}$ of initial $\mathrm{F}^{-}$concentration and adsorbent dose, respectively. It is worth noting that the percentage of $\mathrm{F}^{-}$removal does not weaken in the wide $\mathrm{pH}$ range of 3 to 11 . The adsorption of the $\mathrm{F}^{-}$ions on the synthetic adsorbent is thus not dependent on $\mathrm{pH}$. Kinetic studies revealed that $\mathrm{F}^{-}$adsorption fitted well to pseudo-second-order model indicating the fluoride adsorption mechanism of aluminum-based adsorbent was of chemisorption type.

Furthermore, the adsorption isotherm of $\mathrm{F}^{-}$sorption indicated that the maximum adsorption capacity of this latter was noted to be $43.29 \mathrm{mg} \mathrm{g}^{-1}$. The experimental data indicated that the Langmuir isotherm was a suitable model for describing the $\mathrm{F}^{-}$ adsorption because of its high correlation coefficient.
According to the Langmuir concept, the adsorption of $\mathrm{F}^{-}$onto aluminium-based adsorbent was monolayer adsorption with homogenous distribution of active sites and without interaction between adsorbed molecules. The obtained results indicated that the ion exchange is probably the primary mechanism involved. This study indicated that aluminum-based adsorbent is an efficient material for the removal of fluoride from aqueous solutions, which can be used in water treatment without any additional modification. However, its widespread use is restricted due to high cost. Thus, the search for natural materials such as clays can be an up-andcoming alternative.

\section{Nomenclature}

$C_{0}$ Initial $\mathrm{F}^{-}$concentrations $\left(\mathrm{mg} \mathrm{L}^{-1}\right)$

$C_{\mathrm{e}}$ Equilibrium concentrations of $\mathrm{F}^{-}\left(\mathrm{mg} \mathrm{L}^{-1}\right)$

$K_{\text {ad }}$ Rate constant $\left(\mathrm{min}^{-1}\right)$

$K_{\mathrm{F}}$ Freundlich constants related to adsorption capacity $\left(\mathrm{mg} \mathrm{g}^{-1}\right)$

$K_{1}$ Pseudo-first order rate constant $\left(\mathrm{min}^{-1}\right)$

$K_{2}$ Pseudo-second order rate constant $\left(\mathrm{g} \mathrm{mg}^{-1} \mathrm{~min}^{-1}\right)$

$n \quad$ Adsorption intensity (heterogeneity factor)

$Q_{\mathrm{t}}$ Amount of $\mathrm{F}^{-}$adsorbed per unit mass of adsorbent at time $t$

$Q_{\mathrm{e}}$ Equilibrium adsorbate capacity $\left(\mathrm{mg} . \mathrm{g}^{-1}\right)$

$V$ Volume of the aqueous solution $(\mathrm{mL})$

$W$ Mass of adsorbent ( $\mathrm{g}$ )

$R_{\mathrm{L}}$ Equilibrium parameter

\section{References}

1- N. Mondillo, M. Boni, G. Balassone, S. Spoleto, F. Stellato, A. Marino, L. Santoro, J. Spratt, Rareearth elements minerals in the silius fluorite vein system (sardinia, italy), Ore Geol. Rev., 2016, 74, 211-224. 
2- S.S. Tripathy, J.L. Bersillon, K. Gopal, Removal of fluoride from drinking water by adsorption onto alum-impregnated activated alumina, Sep. Purif. Technol., 2006, 50, 310-317.

3- D.E. Yerien, S. Bonesi, A. Postigo, Fluorination methods in drug discovery, Org. Biomol. Chem., 2016, 14, 8398-8427.

4- Y.P. Xiao, J. Zhang, Y.H. Liu, J.H. Zhang, Q.Y. Yu, Z. Huang, X.Q. Yu, Low molecular weight PEI-based fluorinated polymers for efficient gene delivery, Eur. J. Med. Chem., 2019, 162, 602-611.

5- I. Kaur, B.N. Misra, A. Kohli, Synthesis of Teflon-FEP grafted membranes for use in water desalination, Desalination, 2001, 139, 357-365.

6- K.S. Oh, W. Bae, H. Kim, Dispersion polymerization of $\mathrm{N}$-vinylcarbazole using siloxane-based and fluorine-based surfactants in compressed liquid dimethyl ether, Polymer, 2007, 48, 1450-1454.

7- S. Sasamoto, H. Suzuki, Fluorine-based surfactant, and coating composition and resist composition each using the same, US20130172476A1, 2013.

8- M. Mohapatra, K. Rout, P. Singh, S. Anand, S. Layek, H.C. Verma, B.K. Mishra, Fluoride adsorption studies on mixed-phase nano iron oxides prepared by surfactant mediationprecipitation technique, J. Hazard. Mater., 2011, 186, 1751-1757.

9- J. Dai, Stable electrolytes for high voltage batteries and the batteries derived therefrom, US20110200864A1, 2011.

10-A. Ghosh, K. Mukherjee, S.K. Ghosh, B. Saha, Sources and toxicity of fluoride in the environment, Res. Chem. Intermed., 2013, 39, 2881-2915.

11-L. Deng, Y. Liu, T. Huang, T. Sun, Fluoride removal by induced crystallization using fluorapatite/calcite seed crystals, Chem. Eng. J., 2016, 287, 83-91.

12-D.L. Ozsvath, Fluoride and environmental health: a review, Rev. Environ. Sci. Biotechnol., 2009, 8, 59-79.

13-S. Raghav, D. Kumar, Adsorption equilibrium, kinetics, and thermodynamic studies of fluoride adsorbed by tetrametallic oxide adsorbent, J. Chem. Eng. Data., 2018, 63, 1682-1697.

14-C.Y. Hu, S.L. Lo, W.H. Kuan, Y.D. Lee, Removal of fluoride from semiconductor wastewater by electrocoagulation-flotation, Water Res., 2005, 39, 895-901.

15-H. Huang, J. Liu, P. Zhang, D. Zhang, F. Gao, Investigation on the simultaneous removal of fluoride, ammonia nitrogen and phosphate from semiconductor wastewater using chemical precipitation, Chem. Eng. J., 2017, 307, 696-706.

16-K. Van den Broeck, N. Van Hoornick, J. Van Hoeymissen, R. de Boer, A. Giesen, D. Wilms, Sustainable treatment of HF wastewaters from semiconductor industry with a fluidized bed reactor, IEEE Trans. Semicond. Manuf., 2003, 16, 423-428.

17-N. Zhang, X. Xiao, H. Pang, Transition metal (Fe, $\mathrm{Co}, \mathrm{Ni}$ ) fluoride-based materials for electrochemical energy storage, Nanoscale Horiz., 2019, 4, 99-116.

18-C.-X. Zu, H. Li, Thermodynamic analysis on energy densities of batteries, Energy Environ. Sci., 2011, 4, 2614.

19-A.M.H.R. Hasan, S.K. Sidhu, J.W. Nicholson, Fluoride release and uptake in enhanced bioactivity glass ionomer cement ("glass carbomerTM") compared with conventional and resin-modified glass ionomer cements, J. Appl. Oral Sci., 2019, 27. http://dx.doi.org/10.1590/1678-7757-2018-0230.

20-R.S. Quimby, M. Saad, Pathways to a $4 \mu \mathrm{m} \mathrm{Dy}{ }^{3+}$ Fluoride Glass Fiber Laser, in: Lasers Congr. 2016 ASSL LSC LAC, OSA, Boston, Massachusetts, 2016, 2A-34.

21-J.A. Camargo, Fluoride toxicity to aquatic organisms: a review, Chemosphere, 2003, 50, 251-264.

22-M.A. Karami, Y. Fakhri, S. Rezania, A.A. Alinejad, A.A. Mohammadi, M. Yousefi, M. Ghaderpoori, M.H. Saghi, M. Ahmadpour, Non-carcinogenic health risk assessment due to fluoride exposure from tea consumption in iran using monte carlo simulation, Int. J. Environ. Res. Public Health, 2019, 16, 4261.

23-S. Raghava, D. Kumara, Comparative kinetics and thermodynamic studies of fluoride adsorption by two novel synthesized biopolymer composites, Carboh Poly., 2019, 203, 430-440.

24-M. Yousefi, S. Ghalehaskar, F.B. Asghari, A. Ghaderpoury, M.H. Dehghani, M. Ghaderpoori, A.A. Mohammadi, Distribution of fluoride contamination in drinking water resources and health risk assessment using geographic information system, northwest Iran, J. Reg. Toxicol. Pharm., 2019, 107, 104408.

25-S. Gupta, A.N. Poddar, Sodium fluoride toxicity in the fresh water cat fish clarias batrachus (linn.): effects on the erythrocyte morphology and antioxidant enzymes, Res. J. Environ. Toxicol., 2014, 8, 68-76.

26-A. Dhillon, S. Nehra, D. Kumar, Dual adsorption behaviour of fluoride from drinking water on $\mathrm{Ca}$ $\mathrm{Zn}(\mathrm{OH})_{2} \mathrm{CO}_{3}$ adsorbent, J. Surf. In., 2017, 6, 154-161.

27-M. Ghaderpoori, M. Paydar, A. Zarei, H. Alidadi, A.A. Najafpoor, A.H. Gohary, M. Shams, Health risk assessment of fluoride in water distribution network of Mashhad, Iran, Human and Ecological Risk Assessment: An International Journal, 2019, 25, 851-862.

28-M. Radfard, M. Rahmatinia, H. Akbari, B. Hashemzadeh, H. Akbari, A. Adibzadeh, Data on health risk assessment of fluoride in water distribution network of Iranshahr, Iran, J. Data. Brief., 2018, 20, 1446-1452. 
29-B.L. Riggs, S.F. Hodgson, W.M. O'Fallon, E.Y.S. Chao, H.W. Wahner, J.M. Muhs, S.L. Cedel, L.J. Melon, Effect of fluoride treatment on the fracture rate in postmenopausal women with osteoporosis, N. Engl. J. Med., 1990, 322, 802-809.

30-J. Li, Q. Zhao, Y. Li, Y. Bao, B. Li, H. Yan, S. Huo, Y. Fan, Y. Yang, Y. Gao, Effects of embryonic exposure to fluoride on bone development of zebrafish, Chin. J. Endem., 2018, 37, 24-29.

31-P.T.C. Harrison, Fluoride in water: A UK perspective, J. Fluor. Chem., 2005, 126, 1448-1456.

32-Y. Zhou, C. Yu, Y. Shan, Adsorption of fluoride from aqueous solution on $\mathrm{La}^{3+}$ impregnated cross-linked gelatin, Sep. Purif. Technol., 2004, 36, 89-94.

33-J. Fawell, K. Bailey, J.Chilton, E. Dahi, Y. Magara, Fluoride in drinking- water the first edition, London, UK, IWA publishing, 2006, 97-126.

34-H. Rezaei, A. Jafari, B. Kamarehie, Y. Fakhri, Af. Ghaderpoury, M.A. Karami, M.Ghaderpoori, M. Shams, F. Bidarpoor, M. Salimi, Health-risk assessment related to the fluoride, nitrate, and nitrite in the drinking water in the Sanandaj, Kurdistan County, Iran." Human and ecological risk assessment: an international journal, 2018, $25,1242-1250$.

35-G.C. dos Santos Bazanella, G.F. da Silva, A.M.S. Vieira, R. Bergamasco, Fluoride removal from water using combined Moringa Oleifera/ultrafiltration process, Water. Air. Soil Pollut., 2012, 233, 6083-6093.

36-M. Suneetha, B.S. Sundar, K. Ravindhranath, Removal of fluoride from polluted waters using active carbon derived from barks of Vitex negundo plant, J. Anal. Sci. Technol., 2015, 6,15 .

37-L. Deng, X. Zhang, T. Huang, J. Zhou, Investigation of fluorapatite crystallization in a fluidized bed reactor for the removal of fluoride from groundwater: investigation of fluorapatite crystallization in a fluidized bed reactor for the removal, J. Chem. Technol. Biotechnol., 2019, 94, 569-581.

38-N.S. Graça, A.M. Ribeiro, A.E. Rodrigues, Removal of fluoride from water by a continuous electrocoagulation process, Ind. Eng. Chem. Res., 2019, 58, 5314-5321.

39-V.F. Mena, A. Betancor-Abreu, S. González, S. Delgado, R.M. Souto, J.J. Santana, Fluoride removal from natural volcanic underground water by an electrocoagulation process: parametric and cost evaluations, J. Environ. Manage., 2019, 246, 472-483.

40- Y.-X. Zhang, Y. Jia, Fluoride adsorption on manganese carbonate: Ion-exchange based on the surface carbonate-like groups and hydroxyl groups, J. Colloid Interface Sci., 2018, 510, 407-417.
41-N. Viswanathan, I.A. Kumar, S. Meenakshi, Development of chitosan encapsulated tricalcium phosphate biocomposite for fluoride retention, Int. J. Biol. Macromol., 2019, 133, 811-816.

42-F. Shen, X. Chen, P. Gao, G. Chen, Electrochemical removal of fluoride ions from industrial wastewater, Chem. Eng. Sci., 2003, 58, 987-993.

43-I. Owusu-Agyeman, M. Reinwald, A. Jeihanipour, A.I. Schäfer, Removal of fluoride and natural organic matter from natural tropical brackish waters by nanofiltration/reverse osmosis with varying water chemistry, Chemosphere, 2019, 217, 47-58.

44-S. Parveen, V.N. Ratnakaram, S. Malladi, K. Kiram Kumar, Design of a Domestic Defluoridizing Unit, in: B. Subramanian, S.S. Chen, K.R. Reddy (Eds.), Emerg. Technol. Agric. Environ., Springer, Singapore, 2020, 173-183.

45-X. Wang, N. Li, J. Li, J. Feng, Z. Ma, Y. Xu, Y. Sun, D. Xu, J. Wang, X. Gao, J. Gao, Fluoride removal from secondary effluent of the graphite industry using electrodialysis: Optimization with response surface methodology, Front. Environ. Sci. Eng., 2019, 13, 51.

46-N. Arahman, S. Mulyati, M.R. Lubis, R. Takagi, H. Matsuyama, The removal of fluoride from water based on applied current and membrane types in electrodialysis, J. Fluor. Chem., 2016, 191, 97-102.

47-G. Yan, Y. Bao, M. Tan, Q. Cui, X. Lu, Y. Zhang, Defluorination by Donnan Dialysis with seawater for seafood processing, J. Food Eng., 2018, 238, 22-29.

48-S.I. Bouhadjar, H. Kopp, P. Britsch, S.A. Deowan, J. Hoinkis, J. Bundschuh, Solar powered nanofiltration for drinking water production from fluoride-containing groundwater A pilot study towards developing a sustainable and low-cost treatment plant, J. Environ. Manage., 2019, 231, 1263-1269.

49-G. Crini, E. Lichtfouse, Advantages and disadvantages of techniques used for wastewater treatment, Environ. Chem. Lett., 2019, 17, 145-155.

50-L.S. Thakur, P. Mondal, Simultaneous arsenic and fluoride removal from synthetic and real groundwater by electrocoagulation process: Parametric and cost evaluation, J. Environ. Manage., 2017, 190, 102-112.

51-M. Sarkar, A. Banerjee, P.P. Pramanick, A.R. Sarkar, Use of laterite for the removal of fluoride from contaminated drinking water, J. Colloid Interface Sci., 2006, 302, 432-441.

52-A. Ndé-Tchoupé, R. Crane, H. Mwakabona, C. Noubactep, K. Njau, Technologies for Decentralized Fluoride Removal: Testing Metallic Iron-based Filters, Water, 2015, 7 , 6750-6774.

53-H. Wang, Q. Feng, K. Liu, Z. Li, X. Tang, G. Li, Highly efficient fluoride adsorption from 
aqueous solution by nepheline prepared from kaolinite through alkali-hydrothermal process, J. Environ. Manage., 2017, 196, 72-79.

54-M.T. Hadjyoussef, M. Jendoubi, M.B. Amor, Removal of Fluoride from drinking water by an activated Bentonite: application to a drinking Tunisian water, Mor. J. Chem., 2018, 6, 135-147.

55-K. Kulkarni, G.M. Bhogale, R. Nalawade, Adsorptive removal of fluoride from water samples using Azospirillum biofertilizer and lignite, Korean J. Chem. Eng., 2018, 35, 153-163.

56-L. Deng, Y. Liu, T. Huang, T. Sun, Fluoride removal by induced crystallization using fluorapatite/calcite seed crystals, Chem. Eng. J., 2016, 287, 83-91.

57-M. Mourabet, A. El Rhilassi, H. El Boujaady, M. Bennani-Ziatni, R. El Hamri, A. Taitai, Removal of fluoride from aqueous solution by adsorption on Apatitic tricalcium phosphate using Box-Behnken design and desirability function, Appl. Surf. Sci., 2012, 258, 4402-4410.

58-J.P. Maity, C.-M. Hsu, T.-J. Lin, W.-C. Lee, P. Bhattacharya, J. Bundschuh, C.-Y. Chen, Removal of fluoride from water through bacterial-surfactin mediated novel hydroxyapatite nanoparticle and its efficiency assessment: adsorption isotherm, adsorption kinetic and adsorption Thermodynamics, Environ. Nanotechnol. Monit. Manag., 2018, 9, 18-28.

59-A. Vinati, E.R. Rene, K. Pakshirajan, S.K. Behera, Activated red mud as a permeable reactive barrier material for fluoride removal from groundwater: parameter optimisation and physico-chemical characterisation, Environ. Technol., 2019, 6, 1-12.

60-M. Dessalegne, F. Zewge, W. Mammo, G. Woldetinsae, I. Diaz, Effective fluoride adsorption by aluminum oxide modified clays: Ethiopian bentonite vs commercial montmorillonite, Bull. Chem. Soc. Ethiop., 2018, 32, 199-211.

61-S.S. Tripathy, J.-L. Bersillon, K. Gopal, Removal of fluoride from drinking water by adsorption onto alum-impregnated activated alumina, Sep. Purif. Technol., 2006, 50, 310-317.

62-V.K. Gupta, Suhas, Application of low-cost adsorbents for dye removal-A review, J. Environ. Manage., 2009, 90, 2313-2342.

63-U. Kumari, S.K. Behera, B.C. Meikap, A novel acid modified alumina adsorbent with enhanced defluoridation property: Kinetics, isotherm study and applicability on industrial wastewater, J. Hazard. Mater., 2019, 365, 868-882.

64-D.-C. Shin, S.S. Park, J.H. Kim, S.S. Hong, J.M. Park, S.H. Lee, D.S. Kim, G.D. Lee, Study on $\alpha-$ alumina precursors prepared using different ammonium salt precipitants, Journal of Industrial and Engineering Chemistry, 2014, 20, 1269-1275.

65-NF T 90-004: Water quality - Determination of fluoride ion-Potentiometric method, 2002.
66-A. Dhillon, S.K. Soni, D. Kumar, Enhanced fluoride removal performance by $\mathrm{Ce}-\mathrm{Zn}$ binary metal oxide : Adsorption characteristics and mechanism, J. Fluo. Chem., 2017, 199, 67-76.

67-K.G. Bhattacharyya, S.S. Gupta, Influence of acid activation on adsorption of $\mathrm{Ni}(\mathrm{II})$ and $\mathrm{Cu}$ (II) on kaolinite and montmorillonite: kinetic and thermodynamic study, Chemical Engineering Journal, 2008, 136, 1-13.

68-E.I. Unuabonah, K.O. Adebowale, B.-I. OluOwolabi, Kinetic and thermodynamic studies of the adsorption of lead (II) ions onto phosphatemodified kaolinite clay, Journal of Hazardous Materials, 2007, 144, 386-395.

69-I. Langmuir, The constitution and fundamental properties of solids and liquids, J. Ameri Chem Soci., 1916, 38, 2221-2295.

70-H.M.F. Freundlich, Over the adsorption in solution, The Journal of Physical Chemistry, 1906, 57, 385-471.

71-N. Drouiche, S. Aoudj, M. Hecini, N. Ghaffour, H. Lounici, N. Mameri, Study on the treatment of photovoltaic wastewater using electrocoagulation: Fluoride removal with aluminium electrodes-Characteristics of products. J. Hazard. Mat., 2009, 169, 65-69.

72-L. M. Weinstock, J.M. Stevenson, S.A. Tomellin, S.H. Pan, T. Utne, R.B. Jobson, D.F. Reinhold, Characterization of the actual catalytic agent in potassium fluoride on activated alumina systems. Tetrahedron Letters, 1986, 27, 3845-3848.

73-K.G. Akpomie, A.F. Dawodu, K.O. Adebowale, Mechanism on the sorption of heavy metals from binary-solution by a low-cost montmorillonite and its desorption potential, Alexandria Enginering Journal, 2015, 54, 757-767.

74-M. Massoudinejad, S.M. Mohsenib, M. Ghaderpoori, M. Sarkhosh, Soleyman Sahebi, Improvement of montmorillonite adsorption capacity for lead ions by modifying with hexadecyl trimethyl ammonium chloride: Characterization, modelling and optimization studies, MethodsX, 2019, 6, 2217-2229.

75-K. Sakurai, Y. Ohdate, K. Kyuma, Comparison of salt titration and potentiometric titration methods for the determination of Zero Point of Charge (ZPC), Soil scien. Plant. Nutrition, 1988, 34, 171-182.

76-S.H. Tan, N.A. Ismail, Isotherm and kinetic studies of L-phenylalanine adsorption onto porous nanosilica, Materials, today: Proceeding, 2018, 5, 3193-3201.

77-M.S. Onyango, Y. Kojima, A. Kumar, D. Kuchar, M. Kubota, H. Matsuda Uptake of fluoride by $\mathrm{Al}^{3+}$ pretreated low-silica synthetic zeolites: Adsorption equilibrium and rate studies, Sep. Sci. Technol., 2006, 41, 683-704.

78-S. Ayoob, A.K. Gupta, Insights into isotherm making in the sorptive removal of fluoride from drinking water, J. Hazard. Mater., 2008, 152, 976-985 
79-R.S. Sathish, S. Sairam, V.G. Raja, G.N. Rao, C. Janardhana Defluoridation of water using zirconium impregnated coconut fiber carbon, Sep. Sci. Technol., 2008, 43, 3676-3694.

80-S.K. Swain, R.K. Dey, M. Islam, R.K. Patel, U. Jha, T. Patnaik, C. Airoldi Removal of fluoride from aqueous solution using aluminumimpregnated chitosan biopolymer, Sep. Sci. Tech., 2009, 44, 2096-2116.

81-E. Kumar, A. Bhatnagar, U. Kumar, M. Sillanpää, Defluoridation from aqueous solutions by nano-alumina: Characterization and sorption studies, J. Hazard. Mater., 2011, 186, 1042-1049.

82-M. Barathi, A. S. K. Kumar, N. Rajesh, Aluminium hydroxide impregnated macroreticular aromatic polymeric resin as a sustainable option for defluoridation, J. Environ Chem. Eng., 2015, 3, 630-641

83-B. Meroufel, O. Benali, M. Benyahia, Y. Benmoussa, M.A. Zenasni, Adsorptive removal of anionic dye from aqueous solutions by Algerian kaolin: Characteristics, isotherm, kinetic and thermodynamic studie, J. Mater. Environ. Sci., 2013, 4, 482-491. 